\title{
Stability and Volumetric Properties of Colored Asphalt Mixtures Containing Iron Oxide
}

Authors affiliations:

1) Civil Eng. Dept., Al-Nahrain

University, Baghdad-Iraq.

SamirSamer799@gmail.com

2*) Civil Eng. Dept., Al-Nahrain

University, Baghdad-Iraq.

Alaa.abed@eng.nahrainuniv.edu.iq

\section{Paper History:}

Received: $10^{\text {th }}$ July 2021

Revised: $13^{\text {th }}$ Aug. 2021

Accepted: 11 $1^{\text {th }}$ Sep. 2021

\author{
Samer A. Naji $1^{1}$, Alaa H. Abed ${ }^{2 *}$
}

\begin{abstract}
The objective of this paper is find the effect of using iron oxide as a filler on the Marshall stability, flow and the volumetric properties of HMA and compared the results with conventional HMA using limestone dust. Three blends were used: coarse, mid and fine with neat bitumen (AC 40-50). One aggregate type (crushed) with two types of fillers: limestone and iron oxide III $\left(\alpha-\mathrm{Fe}_{2} \mathrm{O}_{3}\right)$ with three different filler content $6 \%, 8 \%$ and $10 \%$. The Marshall mix design was conducted on the three blends and the optimum binder content is computed for each blend. The Marshall stability test results and the volumetric properties analysis showed that increasing the iron oxide content from $6 \%$ to $10 \%$ increases the stability about $28 \%, 17 \%, 16 \%$ for the coarse , mid and fine mixtures respectively. This increment in stability of mixtures using iron oxide related to the increment in specific gravity of the mix $(\mathrm{Gmb})$ by $(1.3 \%$ to $1.5 \%$ about 30 to $50 \mathrm{~kg} / \mathrm{m} 3)$. On the other hand, the flow of mixtures is decreased about (5\%) for mixes using iron oxide than the ones that used limestone as filler. The fine blend with $10 \%$ iron oxide exhibit the highest stability of $13.3 \mathrm{kN}$. While the coarse blend stability was $10 \mathrm{kN}$ for the same filler type and content. Generally, the Marshall Test results of HMA using iron oxide as filler showed better resistance to plastic deformation, also produce denser HMA with higher stiffness. On the other hand, the volumetric properties analysis showed lesser values as compared with conventional mixture where the void in mineral aggregates and void filled with asphalt has decreased but within the acceptable limits.
\end{abstract}

Keywords: Colored Pavement, Rutting, Modified Binder

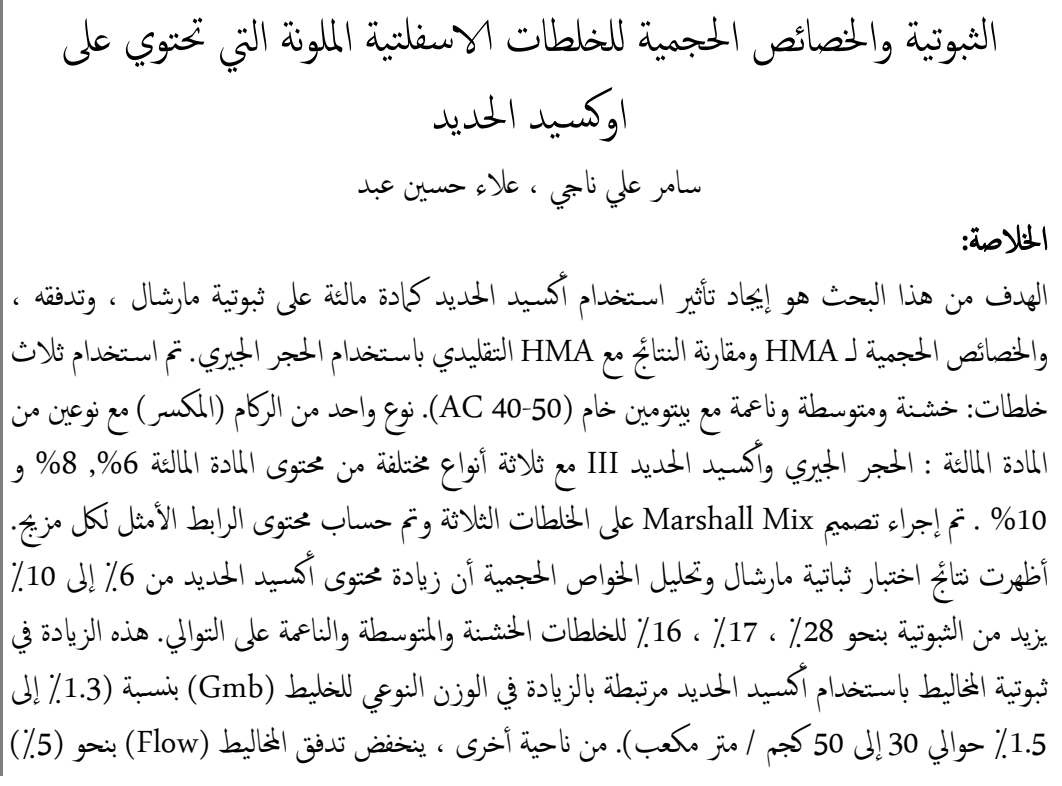




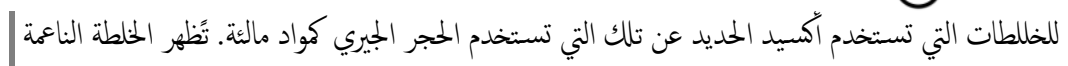

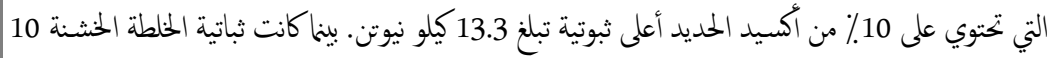

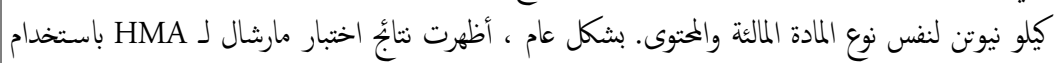

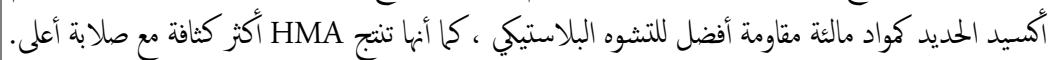

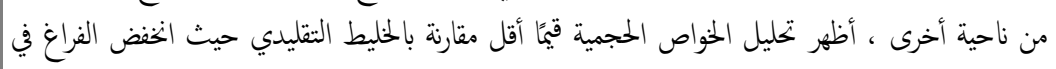

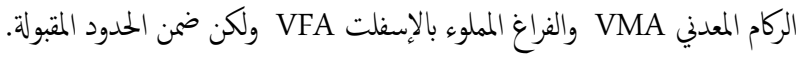

\section{Introduction}

Colored asphalt pavements represent a new pavement technology, it may have different functions such as beautifying cities, increase driving safety, and limiting traffic lanes for buses and bikes therefore it is draw attention over all world recently [1].

Earlier, researchers found out that the asphalt pavements can be colored by using of either pigments (insoluble substances) or colors (water soluble substances) [2].

Lane coloring can be accomplished through one of three methods: painting, applying a colored thermoplastic, laying a thin wearing course of Colored Hot Mix Asphalt (CHMA). Also synthetic clear binder with pigments and polymers was lately used in most of colored pavements [3].

Red Colored hot mix asphalt can be prepared by adding iron oxide as filler [4]. The thickness of the colored wearing course is (30-40 mm) over an asphalt concrete base for roadway and (15-20 mm) over an asphalt concrete base course for the sidewalks [5].

Colored HMA was prepared by using iron oxide as filler to study the stability of the mixture that used in great Seoul children's park. The CHMA was composed of aggregates, iron oxide and neat bitumen AC $85-100$. The aggregate gradation used was $11 \%$, $82 \%, 7 \%$ coarse, fine aggregates and $(5.8 \%$ limestone dust and $1.2 \%$ iron oxide) as filler respectively. The Marshall Stability test results showed that stability was approximately the same of conventional mix. The reason of no increment in stability was the use of excessive fine aggregates than the coarse one which made the HMA deforms easily under high temperature during testing at short time. However, the CHMA satisfied the minimum stability requirement to be used as side walk [5].

Rang et al. (1985) developed a colored binder with a synthetic resin and different colors of paint. The binder performance was similar to petroleum asphalt that satisfies rheological properties and specifications determined by tests such as the Marshall Stability test and wheel tracking test [5].

(Liu et al., 2009) prepared colored styrenebutadiene-styrene-modified emulsified asphalt as a colored binder with colored aggregates and additives to produce colored micro surfaces. Pavement performance tests for the colored pavement produced a high performance meets road requirements and offers advantages such as strong comprehensive performance, safe performance and color stability [6].

(Wu et al., 2014) analyzed the influence of colored pavements on color durability. The test results showed that increasing the adhesion between colored binders and aggregates could improve the color retention [7].
In New York City colored pavements were implemented by red epoxy street paints and they found that epoxy paint was the most durable solution while hot mixed asphalt (HMA)-based micro surfaces were promising [8].

(Lee \& Kim, 2007) studied the effect of using colored synthetic binders of HMA used in bus lanes in Seoul, South Korea. Laboratory test results showed that the designed overlay was of higher strength and lower moisture susceptibility than traditional HMA mixtures [9].

\section{Materials}

\subsection{Asphalt cement}

Neat bitumen (AC 40-50) brought from al Doura refinery was used. The physical properties according to ASTM requirement and State Corporation for Roads and Bridges (SCRB, R9) [9] are shown in Table (1) [11] to [17].

\subsection{Aggregate}

The used aggregates in laboratory work is crushed quartz from Al-Nibaie quarry which is commonly used for asphalt mixes in Baghdad city. Chemical composition and Physical properties of used aggregate are shown in Tables (2) and (3) [18] to [24].

Table (1): Properties of Asphalt Cement, according to ASTM Requirement and Iragi specifications

\begin{tabular}{|c|c|c|c|c|}
\hline \multirow[b]{2}{*}{ Test } & \multirow[b]{2}{*}{$\begin{array}{c}\text { ASTM } \\
\text { Designation }\end{array}$} & \multirow[b]{2}{*}{ Units } & \multicolumn{2}{|c|}{ Penetration Grade 40/50 } \\
\hline & & & $\begin{array}{c}\text { Test } \\
\text { Results }\end{array}$ & $\begin{array}{c}\text { SCRB } \\
\text { Specification }\end{array}$ \\
\hline penetration & D-5 & $\begin{array}{l}1 / 10 \\
\mathrm{~mm}\end{array}$ & 44 & $40-50$ \\
\hline \multirow{2}{*}{$\begin{array}{l}\text { Rotational } \\
\text { viscometer }\end{array}$} & \multirow{2}{*}{ D-4402 } & \multirow{2}{*}{$\begin{array}{l}\text { Pas.se } \\
\quad \mathrm{c}\end{array}$} & $\begin{array}{c}0.56 \\
@ 135^{\circ} \mathrm{C}\end{array}$ & \multirow[b]{2}{*}{...... } \\
\hline & & & $\begin{array}{c}0.19 \\
@ 165^{\circ} \mathrm{C}\end{array}$ & \\
\hline ductility & D-113 & $\mathrm{cm}$ & $>100$ & $>100$ \\
\hline Flash point & D-92 & ${ }^{\circ} \mathrm{C}$ & 275 & Min.232 \\
\hline $\begin{array}{l}\text { Specific } \\
\text { gravity }\end{array}$ & D-70 & $\ldots$ & 1.049 & ...... \\
\hline $\begin{array}{c}\text { Softening } \\
\text { point }\end{array}$ & D-36 & ${ }^{\circ} \mathrm{C}$ & 51 & ...... \\
\hline \multicolumn{5}{|c|}{ Residue from thin film oven test, D-1754 } \\
\hline $\begin{array}{c}\% \\
\text { Retained } \\
\text { penetration } \\
\text { of original }\end{array}$ & D-5 & $\begin{array}{l}1 / 10 \\
\mathrm{~mm}\end{array}$ & 67.4 & $>55 \%$ \\
\hline Mass loss & D-1754 & $\%$ & 0.38 & $<0.75$ \\
\hline $\begin{array}{l}\text { Ductility } \\
\text { of residue }\end{array}$ & D-113 & $\mathrm{cm}$ & 45 & $>25$ \\
\hline
\end{tabular}


Table (2): Chemical Composition of Al-Nibaee (National Center for Construction Laboratories and Researches)

\begin{tabular}{|c|c|}
\hline Chemical compound & Content $\%$ \\
\hline Silica, $\mathrm{SiO}_{2}$ & 84.73 \\
\hline Lime, $\mathrm{CaO}$ & 3.37 \\
\hline Magnwasia, $\mathrm{MgO}$ & 0.53 \\
\hline Sulphuric Anhydride, $\mathrm{SO}$ & 2.9 \\
\hline Alumina, $\mathrm{AlO}$ & 0.62 \\
\hline Ferric Oxide, $\mathrm{FeO}$ & 0.58 \\
\hline Loss on Ignition & 6.25 \\
\hline Total & 98.98 \\
\hline \multicolumn{2}{|c|}{ Mineral Composition } \\
\hline Quartz & 81.2 \\
\hline Calcite & 10.02 \\
\hline
\end{tabular}

Table (3): Physical Properties of Al-Nibaie

\begin{tabular}{|c|c|c|c|c|}
\hline \multicolumn{5}{|c|}{ Aggregate } \\
\hline No & Laboratory test & Designation & $\begin{array}{c}\text { Test } \\
\text { Results }\end{array}$ & $\begin{array}{l}\text { SCRB } \\
\text { Limits }\end{array}$ \\
\hline 1 & $\begin{array}{l}\text { coarse aggregate } \\
\% \text { fractured } \\
\text { particles } \\
(\text { Angularity } \%) \\
\end{array}$ & ASTM D-5821 & 97 & 90 Min \\
\hline 2 & $\begin{array}{l}\text { Fine aggregate } \\
\text { angularity, } \%\end{array}$ & $\mathrm{~T}-304$ & 61 & 45 Min. \\
\hline 3 & $\begin{array}{l}\text { Percent flat and } \\
\text { elongated } \\
\text { Particles, } \%\end{array}$ & ASTM D-4791 & 1.6 & 10 Max. \\
\hline 4 & $\begin{array}{l}\text { Clay content by } \\
\text { Sand } \\
\text { equivalent, } \%\end{array}$ & $\mathrm{~T}-176$ & 51 & 45 Min. \\
\hline 5 & $\begin{array}{c}\text { Toughness, by (Los } \\
\text { Angeles } \\
\text { abrasion), } \%\end{array}$ & T-96 & 15.28 & 30 Max. \\
\hline 6 & $\begin{array}{l}\text { Soundness loss by } \\
\text { sodium sulfate } \\
\text { solution, } \% \\
\end{array}$ & $\mathrm{~T}-104$ & 2.46 & 12 Max. \\
\hline 7 & $\begin{array}{c}\text { Deleterious } \\
\text { materials, } \%\end{array}$ & $\mathrm{~T}-112$ & 0.5 & 3 Max. \\
\hline
\end{tabular}

\subsection{Filler}

The filler used in this work are limestone dust brought from the lime factory in Karbala' governorate, and a synthetic red pigment known as metal oxide $\left(\alpha-\mathrm{Fe}_{2} \mathrm{O}_{3}\right)$ which is inorganic substance obtained from Hamurabi asphalt factory. Figure (1) shows the filler types (Iron oxide III and limestone) used in this research. The physical properties of the used lime filler are presented in Table (4), while the physical and chemical properties of red pigment are presented in Table 5

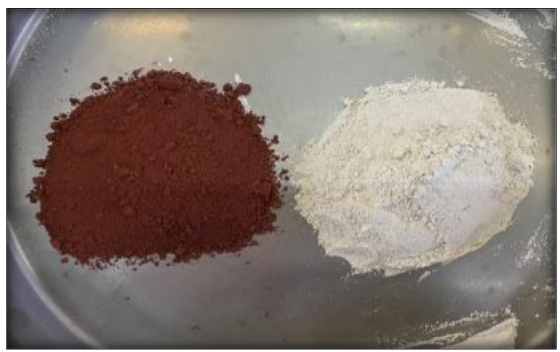

Figure (1): filler type used in this search left: Iron oxide III, right: limestone

Table (4): Physical Properties of limestone Filler

\begin{tabular}{|c|c|}
\hline Property & Test result \\
\hline Specific gravity & 2.73 \\
\hline$\%$ passing sieve No.200 & 98 \\
\hline Specific surface area & 307.3 \\
\hline
\end{tabular}

Table (5): physical and Chemical Properties of red pigment (https://byjus.com/chemistry/iron-oxide/)

\begin{tabular}{|c|c|}
\hline Physical state & Solid, powder \\
\hline color & Red brown \\
\hline Density & $5.24 \mathrm{~g} / \mathrm{cm} 3$ \\
\hline Solubility & $\begin{array}{c}\text { Insoluble in water, } \\
\text { soluble in strong acid }\end{array}$ \\
\hline
\end{tabular}

\section{Job mix formula}

Marshall mix design method was conducted to produce three blend coarse, mid and fine. The job mix formula is selected within (SCRB, R9) limits as shown in Figure (2). Three percent of filler were used 6\%, 8\%, and $10 \%$ for both limestone and iron oxide for each blend.

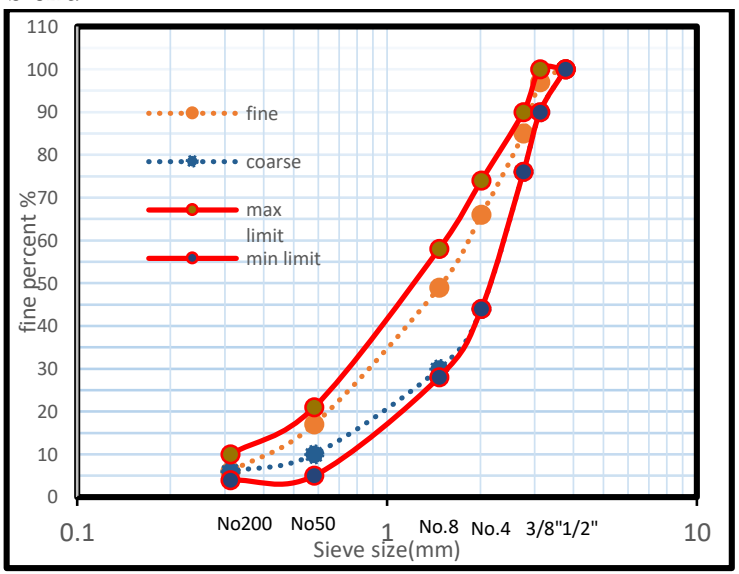

Figure (2): Design job mix formula with SCRB limits

\section{4- Mixing and Compaction Temperature}

According to (ASTM-D6927) [26], the mixing temperature is corresponding to viscosity of $0.17 \pm 0.02$ while the compaction temperature is corresponding to viscosity of and $0.28 \pm 0.03$ Pascal-seconds $(\mathrm{Pa} \cdot \mathrm{s})$. The Rotational Viscometer (RV) has utilized to determine the viscosity of asphalt binder to ensure that the binder is sufficiently fluid (workable) at construction temperatures. As shown in Figure (3) Brookfield Rheometer which is frequently used to measure viscosity at two temperatures $\left(135^{\circ} \mathrm{C}\right.$ and $\left.165^{\circ} \mathrm{C}\right)$. Based on Brookfield Rheometer test, the mixing temperature range was $\left(160^{\circ} \mathrm{C}\right.$ to $\left.163^{\circ} \mathrm{C}\right)$ and the compaction temperature range was $\left(152^{\circ} \mathrm{C}\right.$ to $\left.156^{\circ} \mathrm{C}\right)$ for the used asphalt binder as shown in Figure (4)

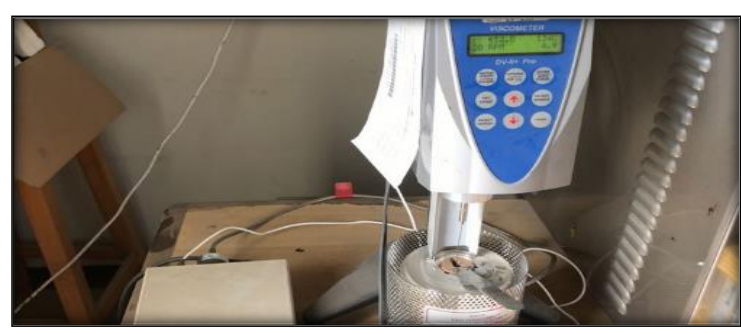

Figure (3): Viscosity test of binder by Brookfield rheometer 


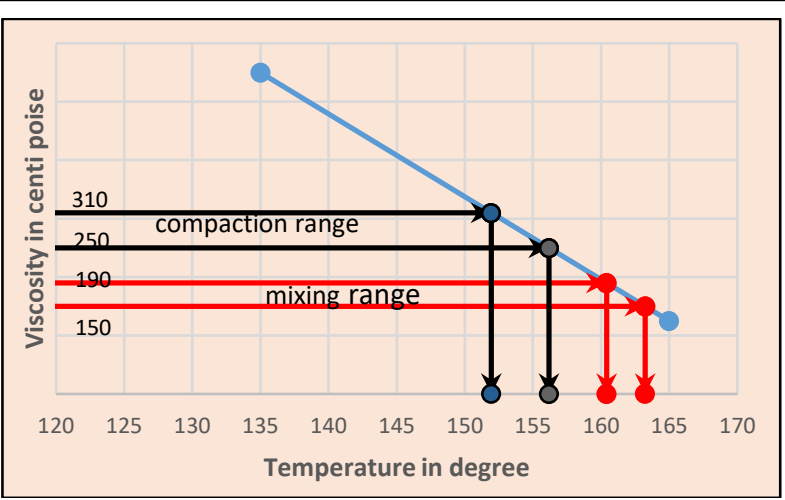

Figure (4): Relation between the number of blows and air void percentage

\section{Marshall Mix design and Optimum Binder Content Determination}

After the samples are prepared (144 samples) as shown in Figure (5) and mixed properly for each type of blend and filler percent, an average of two specimens are prepared at each asphalt binder content for determining the optimum asphalt content. The trial binder contents for the mix design are 4.5\% AC, 5\% AC, $5.5 \% \mathrm{AC}$ and $6 \% \mathrm{AC}$ for all the three blend types. The bulk specific gravity of each sample is computed according to (AASHTO T166-18) [25]. The specimens are compacted by compaction hammer and tested by compression testing machine according to Marshall Method (ASTM-D6927) [26]. The average of binder contents that produce highest stability and specific gravity and gives $4 \%$ air void of particular sample of the mixture is considered as the optimum binder content that SCRB have recommended. Also, the maximum theoretical specific gravity at the estimated binder content is predicted by two specimens according to (AASHTO T 209-20) [27]. The methodology of this work can be represented in Figure 6.

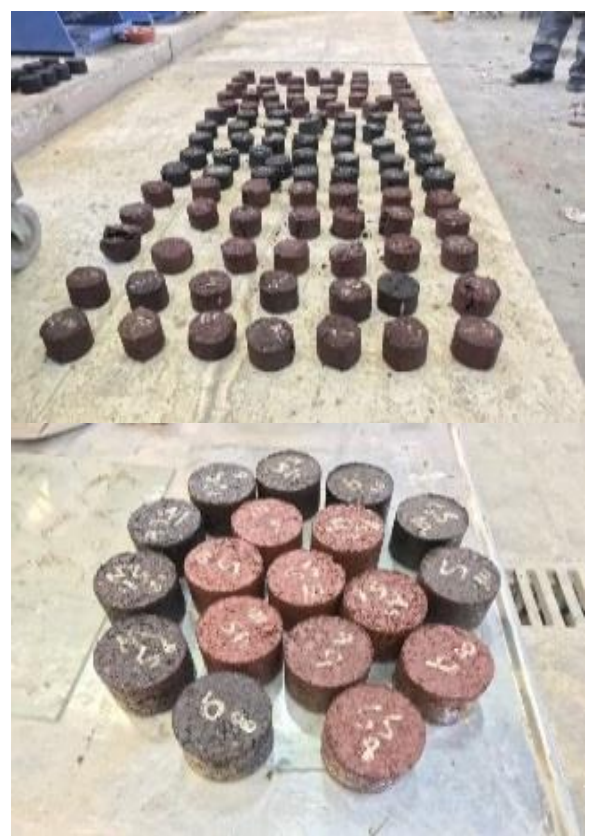

Figure (5): Conventional and colored HMA of Marshall specimens

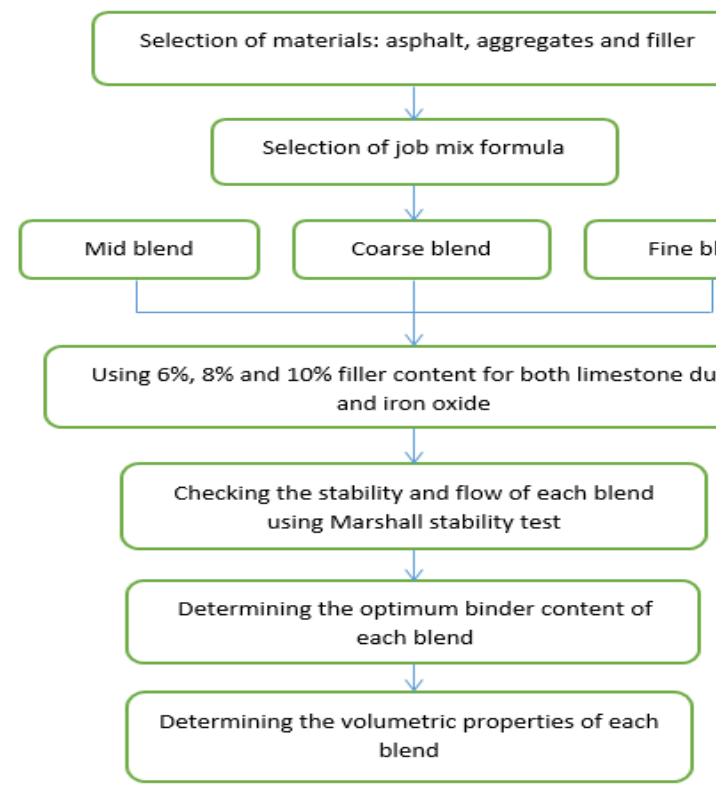

Figure (6): Methodology of presented work

\section{Volumetric properties analysis and results}

After Marshall stability test is accomplished for each specimen, and optimum binder content is determined, the volumetric properties can be computed. The results of Marshall Stability, flow and volumetric properties are shown in Table (6).

Table (6): Marshall Stability, Flow and Volumetric Properties of mixtures at optimum binder content using neat bitumen

\begin{tabular}{|c|c|c|c|c|c|c|c|c|}
\hline $\begin{array}{l}\text { Mix } \\
\text { type }\end{array}$ & $\begin{array}{c}\text { Filler } \\
\%\end{array}$ & $\begin{array}{c}\text { Filler } \\
\text { type }\end{array}$ & $\begin{array}{c}\text { Optimum } \\
\text { binder } \\
\text { content } \\
\%\end{array}$ & $\begin{array}{c}\text { Stability } \\
(\mathrm{KN})\end{array}$ & $\mathrm{Gmb}(\mathrm{gm} / \mathrm{cm} 3)$ & VMA $\%$ & VFA $\%$ & $\begin{array}{l}\text { Flow } \\
(\mathrm{mm})\end{array}$ \\
\hline \multirow{6}{*}{$\begin{array}{l}\text { Coarse } \\
\text { blend }\end{array}$} & \multirow[t]{2}{*}{6} & $\mathrm{~L}^{*}$ & 4.9 & 6.7 & 2.241 & 16 & 74 & 3 \\
\hline & & $\mathrm{R}^{*}$ & 4.8 & 7.8 & 2.275 & 14.85 & 72 & 2.85 \\
\hline & \multirow{2}{*}{8} & $\mathrm{~L}$ & 5.1 & 7.8 & 2.26 & 15.15 & 73.6 & 3.26 \\
\hline & & 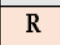 & 5 & 8.9 & 2.295 & 14.19 & 71.8 & 3 \\
\hline & \multirow{2}{*}{10} & $\mathbf{L}$ & 5.2 & 8.6 & 2.296 & 14.2 & 71.8 & 3.42 \\
\hline & & $\mathbf{R}$ & 5.1 & 10 & 2.326 & 14 & 71.4 & 3.3 \\
\hline \multirow{6}{*}{$\begin{array}{l}\text { Mid } \\
\text { blend }\end{array}$} & \multirow[t]{2}{*}{6} & L & 5.2 & 9.3 & 2.26 & 15.3 & 73.8 & 3.25 \\
\hline & & $R$ & 5.1 & 10.3 & 2.293 & 14.75 & 72.8 & 3 \\
\hline & \multirow[t]{2}{*}{8} & $\mathrm{~L}$ & 5.3 & 10 & 2.28 & 14.8 & 73 & 3.5 \\
\hline & & $\mathbf{R}$ & 5.2 & 11.2 & 2.32 & 14.3 & 71 & 3.2 \\
\hline & \multirow{2}{*}{10} & $\mathrm{~L}$ & 5.4 & 10.5 & 2.3 & 14.5 & 72.4 & 3.8 \\
\hline & & $\mathbf{R}$ & 5.3 & 12.1 & 2.341 & 14 & 71.4 & 3.5 \\
\hline \multirow{6}{*}{$\begin{array}{l}\text { Fine } \\
\text { blend }\end{array}$} & \multirow[t]{2}{*}{6} & $\mathrm{~L}$ & 5.6 & 8.6 & 2.281 & 14.9 & 73.1 & 3.6 \\
\hline & & $\mathrm{R}$ & 5.45 & 11.5 & 2.306 & 14.5 & 72.4 & 3.45 \\
\hline & \multirow{2}{*}{8} & $\mathrm{~L}$ & 5.65 & 11.3 & 2.321 & 14.7 & 72.6 & 3.75 \\
\hline & & $R$ & 5.5 & 12.3 & 2.36 & 14.3 & 71 & 3.6 \\
\hline & \multirow[t]{2}{*}{10} & $\mathrm{~L}$ & 5.7 & 11.7 & 2.331 & 14.5 & 72.4 & 3.9 \\
\hline & & $R$ & 5.6 & 13.3 & 2.38 & 14 & 71.4 & 3.75 \\
\hline
\end{tabular}

L* Using limestone as filler

$\mathrm{R}^{*}$ Using iron oxide as filler

From the volumetric properties analysis, Marshall stability and flow determination, it can be seen that the 
marshall stability of blends using iron oxide as filler is more about $(15 \%$ to $20 \%$ about 1.5 to $2 \mathrm{KN})$ than of that using limestone dust as filler. This increment in stability of mixtures using iron oxide related to the increment in specific gravity of the mix $(\mathrm{Gmb})$ by $(1.3 \%$ about $30 \mathrm{~kg} / \mathrm{m} 3)$. The flow of mixtures is decreased about $(5 \%)$ for mixes using iron oxide than the ones that used limestone dust as filler. The interruption of the increment in the density and stability and the decrement in flow for the mixtures using iron oxide that iron oxide leads to increase the viscosity of the asphalt mastic and this obviously noticed when the blend was mixed by hand because the specific gravity of iron oxide is about $83 \%$ more than limestone one . consequently, the stiffness of mastic increased this effect is similar to the effect of polymer (SBS) in HMA.

At $4 \%$ design air void, the Optimum Binder Content(O.B.C) of coarse mix was $4.8 \%, 4.9 \%, 5 \%$ for a filler (iron oxide) 6, 8,10\% respectively and 4.9\% $, 5.1 \%, 5.2 \%$ for a filler (limestone) $6,8,10 \%$ respectively.

For mid mix the O.B.C was $5.1 \%, 5.2 \%, 5.3 \%$ for a filler (iron oxide) 6,8,10\% respectively and $5.2 \%, 5.3 \%, 5.4 \%$ for a filler (limestone) $6,8,10 \%$ respectively.

For the fine mix mix the O.B.C was $5.45 \%, 5.5 \%$, $5.6 \%$ for a filler (iron oxide) $6,8,10 \%$ respectively and $5.6 \%, 5.65 \%, 5.7 \%$ for a filler (limestone) $6,8,10 \%$ respectively.

The specific gravity of mixture (Gmb) is increaesd using iron oxide, hence, the $(\mathrm{Gmm})$ is increased also by the same amount. this an indication that mixtures with iron oxide have less air void content. Consequently, less optimum binder content is needed.

From the volumetric properties analysis the o.b.c for mixtures using iron oxide were less about $2 \%$ than mixtures using limestone.

The Voids in mineral aggregate (VMA) is decreased about $(1-2 \%)$ in mixutres using iron oxide than the ones used limestone as filler, this because the densification of mixture leads to decrease the VMA. Hence, the voids filled with asphalt is decreased as the designed air void is constant. Figure (7) shows a calculation sample of marshall test and volumetric properties analysis.

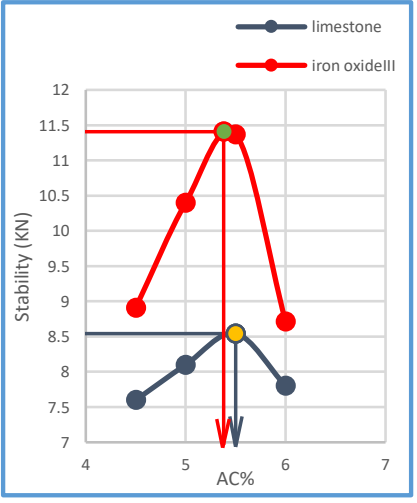

(a)

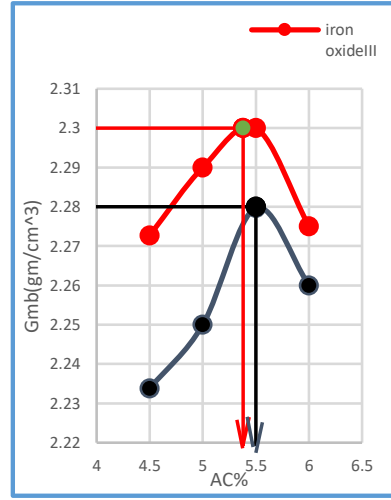

(b)

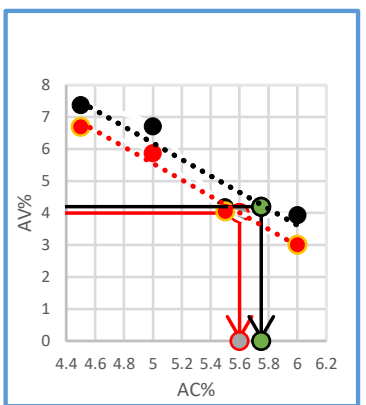

(c)

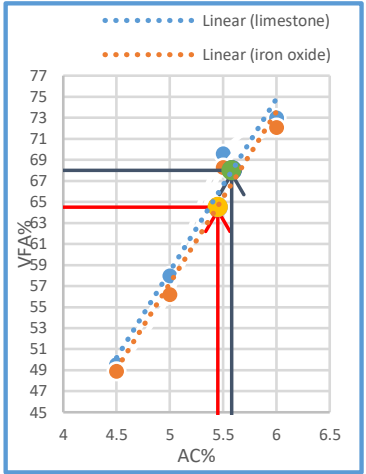

(e)

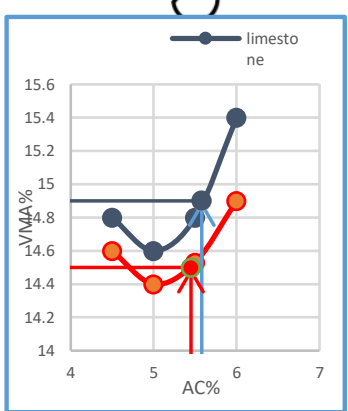

(d)

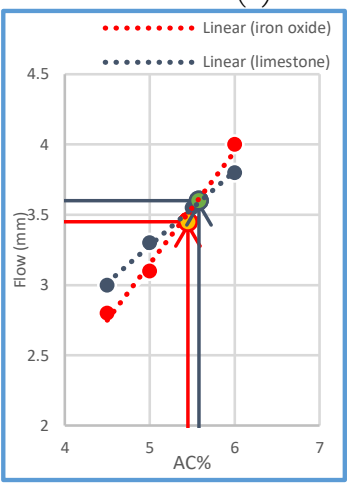

(f)
Figure (7): (a) Marshall Stability, (b) Density, (c) Air void\% (d) Voids in Mineral Aggregate, (e) Voids Filled with Asphalt (f) Flow

\section{Conclusion}

1- The results of Marshall stability, flow and volumetric properties analysis showed that using iron oxide as filler improves the stability of HMA but decrease the flow of mixture due to the stiffening effect for the combination of iron oxide with asphalt make a stronger asphalt mastic in opposite to blends using limestone dust.

2 - The increment in iron oxide content from $6 \%$ to $10 \%$ increases the stability about $28 \%, 17 \%, 16 \%$ for the coarse, mid and fine mixtures respectively. Moreover; the specific gravity of each mix $(\mathrm{Gmb})$ was increased by (1.3\% to $1.5 \%$ about 30 to $50 \mathrm{~kg} / \mathrm{m} 3)$. 3 - It is noted that the optimum binder content of mixture using iron oxide as filler is less than the one using limestone dust by $5 \%$ and that is belonged to the high viscos mastic formed due to the higher specific gravity of iron oxide filler than the limestone one. Consequently, the bulk specific gravity of mixture and the theoretical maximum specific gravity of the mix is increased. As a result, the air void content is decreased. 4- The VMA and VFA for mixtures using iron oxide as filler are decreased as compared to the mixtures using limestone dust as filler at the same binder content but within the acceptable limits.

5- The VMA and VFA of mixtures using $6 \%$ and $8 \%$ of iron oxide is $2 \%$ less than mixtures using limestone dust at same filler content. But, increasing the iron oxide to $10 \%$ leads to $1 \%$ decrement in VMA and VFA.

6- The highest stability against plastic flow of 13.312 .1 and $10 \mathrm{kN}$ for fine, mid and coarse blends respectively at $10 \%$ iron oxide content. 


\section{References:}

[1] Wen-rui Yang, Kai Zhang, Jiao Yuan, Hui-ying Li \& Zhong-min Feng. "Tire-track resistance performance of acrylic resin emulsion coatings for colored asphalt pavements". Road Materials and Pavement Design, 2020.

[2] G\&C Colors, s.a. "Coloured Asphalt Agglomerate”. Cemento Hormign Magazine, 2013.

[3] Flecker, J., Birk, M., Burchfield, R. "Portland's Blue Bike Lanes: Improved Safety through Enhanced Visibility"; UNC Highway Safety Research Center, City of Portland Office of Transportation: Portland, OR, USA, 1999.

[4] Tullio Giuffrè, Marco Morreale, Giovanni Tesoriere, Salvatore Trubia. "Rheological Behaviour of a Bitumen Modified with Metal Oxides Obtained by Regeneration Processes". Faculty of Engineering and Architecture, University of Enna Kore, Viale delle Olimpiadi, 94100 Enna, Italy, 2018.

[5] Kim Rang W. Lee.;M. ASCE, Ju Won Kim.;and Dae Woong. "Development of Color Pavement in Korea". Journal of Transportation Engineering, Vol. I 11, No. 3, May, 1985.

[6] Liu, S. W.;Du, S. J.; Niu, Q. Y.; Zhang, M. "Research and Application on Colorized MicroSurfacing". Journal of Taiyuan University of Technology, 5(40), 513-517, 2009.

[7] Wu, C. H., Xu, C., \& Xu, M. “Colour Durability Analysis of Colored Asphalt Concrete". Engineering Material \& Equipment, 1(32), 162-164, 2014.

[8] William Carry, Eric Donnell, Zoltan Rado, Martin Hartman, and Steven Scalici. "Red Bus Lane Treatment Evaluation”. New York City Department of Transportation and the Pennsylvania State University, 2012.

[9] H. Lee and Y. Kim. "Laboratory Evaluation of Color Polymer Concrete Pavement with Synthetic Resin Binder for Exclusive Bus Lanes". Transportation Research Board of the National Academies, Washington, D.C., pp. 124-132, 2007.

[10] SCRB/R9. "General Specification for Roads and Bridges, Section R/9, Hot-Mix Asphalt Concrete Pavement", Revised Edition. State Corporation of Roads and Bridges, Ministry of Housing and Construction, Republic of Iraq, 2003.

[11] ASTM D 5. "Standard Test Method for Penetration of Bituminous Materials" Annual Book of ASTM Standards. American Society for Testing and Materials," West Conshohocken, USA, 2005.

[12] ASTM D 4402. "Standard Test Method for Viscosity Determination of Asphalt at Elevated Temperatures Using a Rotational Viscometer". Annual Book of ASTM Standards. American Society for Testing and Materials," West Conshohocken, USA, 2015.

[13] ASTM D 113. "Standard Test Method for Ductility of Asphalt Materials". Annual Book of ASTM Standards. American Society for Testing and Materials," West Conshohocken, USA, 2017.

[14] ASTM D 92. "Standard Test Method for Flash and Fire Points by Cleveland Open Cup Tester". Annual Book of ASTM Standards. American Society for Testing and Materials," West Conshohocken, USA, 2018.

[15] ASTM D 70. "Standard Test Method for Specific Gravity and Density of Semi-Solid Asphalt Binder (Pycnometer Method)". Annual Book of ASTM Standards. American Society for Testing and Materials," West Conshohocken, USA, 2018.

[16] ASTM D 36. "Standard Test Method for Softening Point of Bitumen (Ring-and-Ball Apparatus)". Annual Book of ASTM Standards. American Society for Testing and Materials," West Conshohocken, USA, 2018.

[17] ASTM D 1754. "Standard Test Method for Effects of Heat and Air on Asphaltic Materials (ThinFilm Oven Test)" .Annual Book of ASTM Standards. American Society for Testing and Materials," West Conshohocken, USA, 2018.

[18] ASTM D 5821. "Standard Test Method for Determining Percent of Fractured Particles in Coarse Aggregate" Annual Book of ASTM Standards. American Society for Testing and Materials," West Conshohocken, USA, 2009.

[19] AASHTO T 304. "Standard Test Method for Uncompacted Void Content of Fine Aggregate". The American Association of State Highway and Transportation Officials, Washington, D. C., USA, 2017.

[20] ASTM D 4791. "Standard Test Method for Flat Particles, Elongated Particles, or Flat and Elongated Particles in Coarse Aggregate". Annual Book of ASTM Standards. American Society for Testing and Materials,” West Conshohocken, USA, 2019.

[21] AASHTO T 176. "Standard Method of Test for Plastic Fines in Graded Aggregates and Soils by Use of the Sand Equivalent Test". The American Association of State Highway and Transportation Officials, Washington, D. C., USA, 2017.

[22] AASHTO T 96. "Standard Method of Test for Resistance to Degradation of Small-Size Coarse Aggregate by Abrasion and Impact in the Los Angeles Machine". The American Association of State Highway and Transportation Officials, Washington, D. C., USA, 2002.

[23] AASHTO T 104. "Standard Method of Test for Soundness of Aggregate by Use of Sodium Sulfate or Magnesium Sulfate". The American Association of State Highway and Transportation Officials, Washington, D. C., USA, 2003.

[24] AASHTO T 112. "Standard Method of Test for Clay Lumps and Friable Particles in Aggregate". The American Association of State Highway and Transportation Officials, Washington, D. C., USA, 2004.

[25] AASHTO T 166. "Standard Method of Test for Bulk Specific Gravity (Gmb) of Compacted Asphalt Mixtures using Saturated Surface-Dry Specimens" The American Association of State Highway and Transportation Officials, Washington, D. C., USA, 2018.

[26] ASTM D 6927 "Standard Test Method for Marshall Stability and Flow of Asphalt Mixtures" Annual Book of ASTM Standards. American Society for Testing and Materials," West Conshohocken, USA, 2015. 
NJES 24(2)130-136, 2021

Naji \& Abed

[27] AASHTO T 209. "Standard Method of Test for Association of State Highway and Transportation Theoretical Maximum Specific Gravity (Gmm) and Officials, Washington, D. C., USA, 2020.

Density of Asphalt Mixtures". The American 